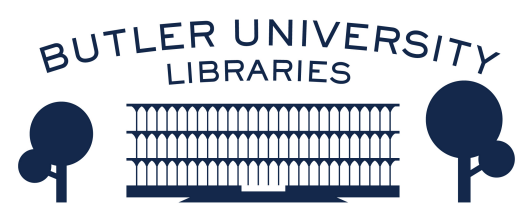

Journal of Hindu-Christian Studies

Volume 27

Article 15

November 2014

\title{
Book Review: His Hiding Place is Darkness: A Hindu-Catholic Theopoetics of Divine Absence.
}

Rico G. Monge

University of San Diego

Follow this and additional works at: https://digitalcommons.butler.edu/jhcs

Part of the History of Religions of Eastern Origins Commons

\section{Recommended Citation}

Monge, Rico G. (2014) "Book Review: His Hiding Place is Darkness: A Hindu-Catholic Theopoetics of Divine Absence.," Journal of Hindu-Christian Studies: Vol. 27, Article 15.

Available at: https://doi.org/10.7825/2164-6279.1587

The Journal of Hindu-Christian Studies is a publication of the Society for Hindu-Christian Studies. The digital version is made available by Digital Commons @ Butler University. For questions about the Journal or the Society, please contact cbauman@butler.edu. For more information about Digital Commons @ Butler University, please contact digitalscholarship@butler.edu. 
interested in comparative religious ethics-and, particularly, the ethics of self-gift, altruism and social egalitarianism. A preface by the Dalai Lama adds gravitas to the study, and helps to situate it more firmly as the truly constructive proposal that it is. It will reward close reading by students of Advaita, Buddhism and moral philosophy.

Reid B. Locklin

St. Michael's College, University of Toronto

\section{His Hiding Place is Darkness: A Hindu-Catholic Theopoetics of Divine Absence. Francis X. Clooney, S.J. Stanford, CA: Stanford University Press, 2013, 208pp.}

WITH his opening words, Francis Clooney indicates to his reader that the content of His Hiding Place is Darkness is "first of all" a reading of the Hebrew Song of Songs alongside the Hindu Holy Word of Mouth. Nevertheless, he maintains, what "matter most" throughout the text are the themes of "love and the absence of the beloved" (ix). These two components form an apt description of the book, the body of which is divided into three "Acts" and two "Entr'actes." Each of the Acts is constituted by a reading of these sacred texts together, while the "Entr'actes" draw on theologians and poets in order to highlight the aforementioned themes Clooney wishes to emphasize in carrying out his comparative theological task.

True to form, Clooney does not read these works in a vacuum, but rather according to dominant traditions of interpretation in his native Roman Catholicism and in Srivaishnava Hinduism. Accordingly, he explores the Song of Songs in dialogue with Bernard of Clairvaux (1090-1153), Gilbert of Hoyland (twelfthcentury), and John of Ford (1140-1214), while reading the Holy Word of Mouth with Nanjiyar (1182-1287) and Nampillai (thirteenthfourteenth century). By employing this strategy, Clooney engages in the comparative theological task while remaining firmly grounded in the hermeneutics set forth by authoritative interpreters within these respective religious traditions. According to these interpretive traditions, both texts concern a woman's longing after her sometimes absent beloved, but the deeper importance of these poems is that they allegorically represents the relationship between the believer and their beloved divinity (here, Christ and Krishna, respectively).

What both texts intensify in each other, when read together, is the sense that the beloved divinity, whether it be Christ in the medieval Christian reading of the Song or Krishna in the Srivaishnava reading of the Holy Word, is absent and longed for because he often appears absent. Both texts emphasize "being alone, searching, and in the face of absence, conjuring the beloved in fierce remembrance" (45). Reading these texts together helps to further unsettle the reader's sense of the identity of the divine, Clooney argues, because it ensures that "we escape with no easy discovery of the beloved" (31). In order to demonstrate how it is possible to so deeply unsettle even the identity of the divine and still be engaging in theology, Clooney draws, in the 
"Entr'actes," on Hans Urs von Balthasar's "theopoetic" reading of Gerard Manley Hopkins, as well as upon the contemporary poet Jorie Graham. From Balthasar and Hopkins, Clooney is able to argue that a "Christic reading of our world, abundant and generous" can still be deeply aware that this same Christic and abundant generosity is "not something, someone we control" as our "object of speech" (30). Similarly, Jorie Graham's work shows us that in speaking poetically we acknowledge that we are bound to fail when speaking, but we may still "fail with difficulty, and productively" (36). Clooney thus reveals that the task of theology (a task unveiled more clearly in the comparative mode) is best understood not as an action of dogmatic definition and delimitation, but rather as a never-ending process of patient searching, longing, finding, losing, and finding again.

One of the great contributions of His Hiding Place is Darkness is that it is a text that skillfully and beautifully draws the reader into understanding that "loving God is always a risk" (141). Clooney points out that this theme is even more relevant today because the absence of God and the vulnerability one experiences in loving God is felt more acutely in disenchanted modernity. Although he does not make this explicit, Clooney's vision thus runs counter to impulses the Christian theological tradition inherited from Augustine, for whom our hearts are always restless until they rest in God, and for whom the love of God grants the only possible indemnification against risk and loss. Clooney's engagement with both the Christian and Hindu traditions demonstrates instead that restlessness, longing, and the perception of divine absence are necessary elements of loving the divine that invite us to a productive theological uncertainty. Clooney is by no means the only Roman Catholic theologian stressing that theology should embrace uncertainty and infinite longing (cf. especially Jean-Luc Marion's The Idol and Distance and God without Being), but he differs from many of these other voices in His Hiding Place is Darkness by stressing that such uncertainty and longing invites useven implores us-to engage the religious other. Clooney demonstrates this not only through illuminating two traditions with sacred love poems disclosing similar themes; he does so through the interreligious encounter itself, which he calls "a dramatic arena home to partly told and still unfinished stories of God and love, incompletely recounted encounters, dialogues without clear beginnings or certain endings, the beloved nearby and gone missing, more than once" (124).

His Hiding Place is Darkness does, however, leave us with significant questions regarding the task of comparative theology and its engagement with the other. Does the comparative task seek merely to intensify convictions that can already be found in one's home tradition? Or is there also openness to reifying the interpretation of one's own tradition in light of another's? In the end, it remains unclear if the subtitle of Clooney's volume is achieved. Do we arrive at a truly Hindu-Catholic theopoetics of divine absence? Or do we instead find a Catholic theopoetics intensified by engaging similar themes in Hinduism? Moreover, would the theological takeaway be substantially different if a Sufi text had been considered instead of a Hindu one? Towards the end of the text, Clooney poignantly asserts, "Total devotion to Jesus as the one and only beloved-faithful, true, and 
sometimes missing, hiding, not coming back, nowhere else-shines better in a world where we need not forget this Krishna about to return to the young woman waiting in the garden" (141). This reader wholeheartedly agrees, but still wonders does it merely shine more brightly, or might we not dare to go further and ask how it shines differently?

His Hiding Place is Darkness is a beautifully and skillfully written text and should be of interest to a wide variety of readers. In its "Acts," Clooney gives us one of the only extended studies of the Holy Word in the English language, and for this reason it makes a significant contribution for readers focused on
Hindu studies. In particular, it should be of interest to any Christian theologian (whether of comparative inclinations or not) concerned with the relationship between theological knowledge and the obstacles posed by modernity and religious pluralism. What of Hindu readers with theological commitments to Krishna? Their engagement with the book is essential if we are to further explore what it might mean to develop a Hindu-Catholic theopoetics.

Rico G. Monge

University of San Diego

\section{The Divine Body in History: A Comparative Study of the Symbolism of Time and Embodiment in St. Augustine and Rāmānuja. Ankur Barua. New York: Peter Lang, 2011, 253 pp.}

IN The Divine Body in History Dr. Ankur Barua of Cambridge University presents an incisive study in the comparative philosophy of religion. As the book proceeds, the line between philosophy of religion and theology blurs, making the book a significant contribution to comparative theology as well.

Dr. Barua addresses two themes in The Divine Body: time and embodiment. He then compares two influential theologians on these topics: Rāmānuja and Augustine. His choice of figures serves to correct the unstudied assumptions that Hindu thought is ahistorical and Christian thought is anti-body. Instead, Dr. Barua argues that Rāmānuja is carefully attentive to history and Augustine (particularly the later Augustine) valorizes embodiment as the intention of our Creator, the maker of all things visible and invisible. His choice of themes allows Dr. Barua to correct two common misinterpretations. His comparative method grants him insight into each thinker, read in the light of the other, making for a more powerful exposition.

Dr. Barua adopts the comparative method as a demand of our theological age. The contemporary theological context is irretrievably pluralistic, presenting theologians not only with "other" answers, but with "other" questions as well-questions they have never answered, or may never have asked. Thus, we find our religious selves in a context of otherness in which the old monological thought seems flat and ineffective. This new, interreligious universe demands multilogical thought best nurtured through dialogue among traditions (2). 